Available online at

INSECTA

Integrative Science Education and Teaching Activity Journal

Journal homepage : https://jurnal.iainponorogo.ac.id/index.php/insecta

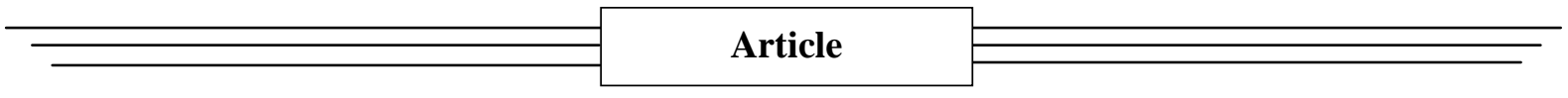

\title{
Websites as Science Learning on Invertebrate Animals Materials at State Junior High School 1 Tegaldlimo Banyuwangi
}

\author{
Etika Rosyida $^{1^{*}}$, Rafiatul Hasanah $^{2}$ \\ 1,2 Jurusan Tadris Ilmu Pengetahuan Alam, Universitas Islam Negeri (UIN) KH. Achmad Shiddiq Jember , Indonesia \\ *Corresponding Address: etikarosyida77@ gmail.com
}

\section{Article Info}

Article history:

Received: September 29, 2021

Accepted: October 30, 2021

Published: November 29, 2021

\section{Keywords:}

Learning Media

Development

Website

\begin{abstract}
This study aims to determine the validity of the development of websitebased science learning media on invertebrate animal material for grade 7 in Junior High School, and to determine student responses to the development of website-based science learning media on invertebrate animal material. This research was a type of $\mathrm{R} \& \mathrm{D}$ (Research and Development) research which refers to the ADDIE (Analysis, Design, Development, Implementation and Evaluation) development research model of Robert Maribe Branch. The data collection instruments in this study were validation questionnaires and student response questionnaires. Validation was carried out by material experts, media experts, and science teachers. The development trial to determine student responses to the developed product was carried out in two stages, namely a small-scale trial consisting of 6 students and a large-scale trial consisting of 32 students. Based on the results of validation from experts on website-based science learning media, it showed that the assessment of material experts was $96.16 \%$, media expert assessments was $89.12 \%$ and assessments from science teachers was $89.83 \%$. In this case, the average percentage of the expert's assessment was $91.70 \%$, which means it was included in the "Very Valid" category and tested on students, and Small-scale trials obtained an average percentage of $94.28 \%$. Then continued large-scale trials and obtained an average percentage of $92.00 \%$. which means "Very Interesting".
\end{abstract}

(C) 2021 Etika Rosyida, Rafiatul Hasanah.

\section{INTRODUCTION}

Natural Sciences (IPA) is a science that is built based on observation and data classification, involving the application of mathematical reasoning and data analysis on natural phenomena (Metilistina Sasinggala et al., 2020). Science is a subject that has a close relationship with the surrounding environment and daily life, this of course affects science learning activities.

Science learning is a process of seeking experience and producing mastery of knowledge in the form of understanding concepts (Mamik Suendarti and Hasbullah, 2020). 
The learning process is built to develop students' creative thinking, and can improve the ability to construct new knowledge as an effort to improve good mastery of subject matter (Ni Kadek Ayu Dwi Arini et al., 2020). Through science learning students can understand the surrounding environment, apply scientific concepts in everyday life, and can explain scientifically natural phenomena that occur in their environment. However, this will be realized if students have really mastered the material being studied (I Made Alit Mariana and Wandy Praginda, 2009).

The results of Anis Wahdati Sholekah's research show that student learning outcomes in science are still low compared to other subjects. Many students have not reached the KKM, which is 76, so it has an impact on the percentage of learning outcomes. The average value of science learning outcomes is 35.10 so they have to do remedial. This can happen because there is quite a lot of science material so that students have difficulty in learning (Anis Wahdati Sholekah, 2020). One of the science materials that is considered quite difficult is invertebrate animal material.

According to Dania Kurrotul A'yun and Erman (2019) in a science education journal entitled the ability of students to classify the invertebrate kingdom animalia, they explained that: the classification of living things is one of the difficult materials, namely the classification of the invertebrate kingdom animalia. In invertebrate material there is a wide range of material, difficulties in understanding Latin, difficulty in determining roles, classifying and describing the characteristics of each phylum, learning time and the availability of limited learning resources and media. This proves that the ability of students in classifying the invertebrate kingdom animalia is still low. So that it affects the achievement of the objectives of the basic competencies in the material (Dania Kurrotul A'yun and Erman, 2019). Therefore, teachers need to use a medium to convey the material.

Media is a tool or material to make it easier to channel information to someone. Media in the learning process can be in the form of images, graphic tools, distribution of visual or verbal information (Norma Azizah et al., 2020). Learning media is anything that can be used to channel information from educators to students. So that it can stimulate thoughts, feelings, attention and interests as well as the will that is arranged in such a way that the learning process runs as desired in order to achieve learning objectives effectively (Ilmawan Mustaqim, 2016). Learning media is one of the impacts of today's technology. Along with its development which is increasing day by day, it can provide various facilities for humans to carry out all their activities in daily activities. But the facts on the ground show that the teaching and learning process in the classroom is still not optimal. This is in line with the results of interviews conducted with one of the science teachers at SMP Negeri 1 Tegaldlimo, showing that: 1) The lack of learning media in schools. 2) Have never used website-based learning media. 3) The lack of learning resources in schools. Based on these findings, schools need supporting media for the learning process.

The role of learning media is very important to improve the effectiveness of the teaching and learning process, as follows: 1) Enriching the learning experience of students, 2) Economical, 3) Increasing students' attention to lessons, 4) Making students more ready to learn, 5) Involving many senses in the learning process, 6) Minimize differences in perceptions between teachers and students, 7) Increase students' positive contribution in gaining learning experiences and 8) Help resolve personal differences between students (Abdul Haris Pito, 2018).

One of the media that can be used as an alternative in learning is website-based learning media. This media is suitable with the mater/ topic about invertebrate. Invertebrate have many phylums. In invertebrate animal material there are 8 classifications, in each classification there are several classes so that students difficult to remember the material presented, therefore the researcher developed this website-based learning media to make it 
easier for students to learn. Furthermore, based on observation in SMPN 1 Tegaldlimo that there are very limited school package books, and based on learner needs analysis. Researcher find that the students need the learning media which can be read at home, because at that time online or learn from home (LFH), so that the students no need to bring or borrow the package books from school. These some reasons why teh researcher developing this website based learning media. The media of this website is not only equipped with material, but also includes pictures of animals so that students can remember them easily. The website is an information system site page that can be accessed quickly (Bahagia and Sriwinar, 2021). Website is a system with information presented in the form of text, images, sound, etc. which is stored on an internet web server in the form of hypertext. Web information in text form is generally written in HTML (Hypertext Markup Language) format (Erico Aprianus and Julianti Kasih, 2021).

Website-based learning is one part of the use of the internet in education. The advantages of learning using the internet include the following: 1) It allows everyone anywhere and anytime to learn anything; 2) Learners can learn according to their own characteristics and steps because web-based learning makes learning individual; 3) Ability to create links, so that learners can access information from various sources, both inside and outside the learning environment; 4) Potential as a learning resource for learners who do not have enough time to study; 5) Encouraging learners to be more active and independent in learning; 6) Provide additional learning resources that can be used to enrich learning materials; 7) Provide a search engine that can be used to find the information they need; and 8) The content of the subject matter can be updated easily (Hamzah B. Uno and Abd. Rahman K. Ma'ruf, 2016).

Based on the description above, researchers are interested in research related to "Websites as Science Learning Media in Class VII Invertebrate Animals Materials at SMP Negeri 1 Tegaldlimo Banyuwangi". The hope is that it can improve students' understanding of the classification of invertebrate animals, students' ability to explain the characteristics and roles of invertebrate animals.

\section{METHODS}

This research is a development research commonly called Research and Development. This study aims to produce a product in the form of a website-based science learning media on invertebrate animal material for seventh grade students of junior high school. This study uses a model developed by Robert Maribe Branch, namely ADDIE which consists of five stages, the five stages are: Analysis, Design, Development, Implementation and Evaluation. However, in this study only up to the Development stage, this is due to the limited time and costs of the researcher.

The method used in this study is presented in the following flow chart. See in Figure 1. 


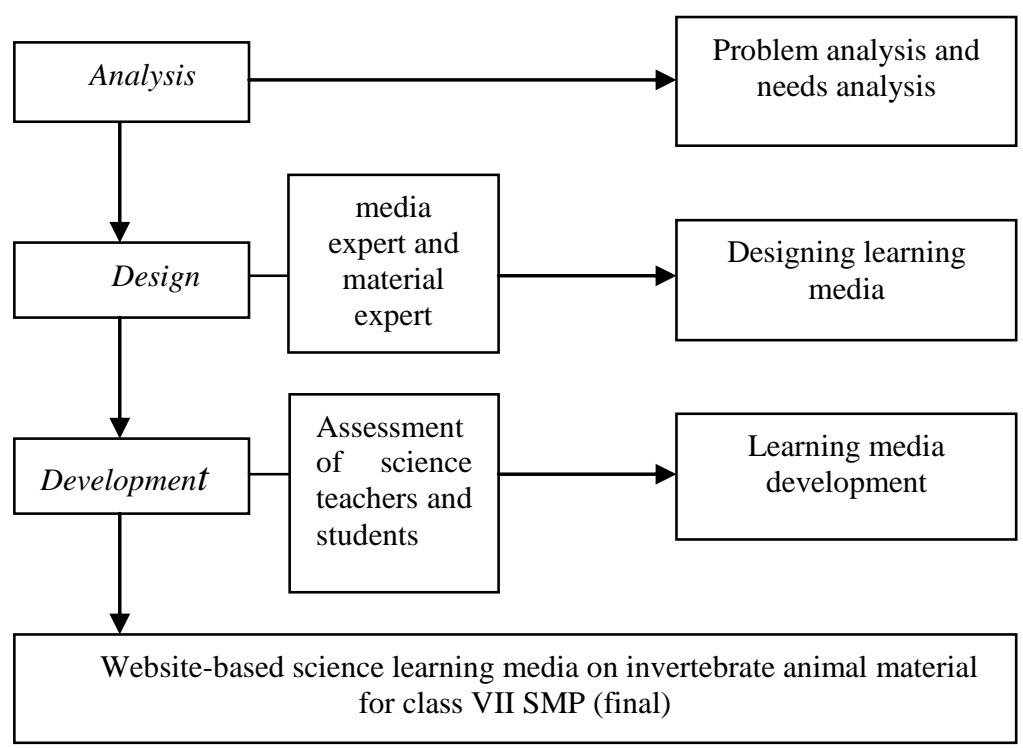

Figure 1. Steps for developing website-based science learning media

The development steps carried out in this study are described as follows: Analysis, this analysis phase consists of performance analysis, needs analysis, and curriculum analysis. Performance analysis is carried out to find out the problems that exist in the school, needs analysis is carried out to determine the learning media needed by students so that it attracts interest in learning, and the analysis is used to select the desired science subjects. The second step is Design, with the following stages: compiling learning materials, selecting media that are tailored to the analysis of problems and needs, preliminary design is carried out to design initial learning media activities before being tested by designing learning media formats and instruments for selecting formats and instrument analysis including validation of material experts, instruments media expert validation and student response questionnaires. And the final step is Development, this development involved 3 lecturers and students who were tested.

\section{RESULTS AND DISCUSSION}

The steps in making a product include product design, final product, expert validation including material experts, media experts, and small-scale and large-scale student responses. The process of making web-based learning media, namely, making the required documents in the media using the Microsoft Word application, then using the power point application to design the desired concept. Then publish it to a website using a computer, the page is created using HTML (Hyperlink Text Markup Language) so that the web page can be displayed in the desired format. HTML has many limitations for that it requires other tools, namely PHP as a scripting language and MySQL as a database server. So that the artistic aspects of a web page are more optimal and can be managed with certain templates, CSS (Cascading Style Sheet) is needed. After getting a view-based assembly process (domain name rental, web hosting, as well as programming language mastery), the main page results in a media website. The main page is designed with user needs so that website-based media is more structured.

The final product of the development of this learning media is a website-based learning media. The specifications of the media that have been developed can be seen in the Table 1 .

Table 1.The sample of table format

\begin{tabular}{rcc}
\hline No & Specification & Description \\
\hline 1 & Learning media & Invertebratatadrisipa.com/ \\
& website address & Invertebrate animals \\
2 & Making materials & By online \\
3 & Access & 66 \\
4 & Number of slides & Opening page, instructions for \\
5 & Content
\end{tabular}




\begin{tabular}{ccc}
\hline No & Specification & Description \\
\hline & & use, core competencies, basic \\
& competencies, learning \\
& objectives, concept maps, \\
& materials, practice questions, \\
& bibliography and profiles \\
& Microsoft word, power point \\
6 & Maker app & and website
\end{tabular}

In this product of the development of website based learning media there are some of the menus on the website and their contains. The menus and content can be seen in the table 2 .

Table 2. Some menus and their contains

\begin{tabular}{|c|c|c|}
\hline No & Menu & Contains \\
\hline 1 & Cover page & $\begin{array}{l}\text { Logo of IAIN Jember, sub } \\
\text { topic, start navigation }\end{array}$ \\
\hline 2 & Main page & $\begin{array}{l}\text { Guideline for use, } \\
\text { competencies, mind mapping, } \\
\text { materials, practice questions, } \\
\text { bibliography and profiles. }\end{array}$ \\
\hline 3 & User guideline & $\begin{array}{l}\text { How to run the media } \\
\text { correctly and contains the } \\
\text { functions of the navigation } \\
\text { buttons contained in the media }\end{array}$ \\
\hline 4 & Competence & $\begin{array}{c}\text { In the competencies there } \\
\text { are core competencies and basic } \\
\text { competencies and learning } \\
\text { objectives }\end{array}$ \\
\hline 5 & $\begin{array}{l}\text { Concept map/ mind } \\
\text { mapping }\end{array}$ & $\begin{array}{l}\text { Form of a flow chart that show } \\
\text { about phylums of eight phyla of } \\
\text { invertebrate animal }\end{array}$ \\
\hline 6 & Materials & $\begin{array}{c}\text { Contains } 8 \text { phyla which } \\
\text { including: Porifera, Cnidaria, } \\
\text { Platyhelminthes, } \\
\text { Nemathelminthes, Annelida, } \\
\text { Mollusca, Arthropoda and } \\
\text { Echinoderms }\end{array}$ \\
\hline 7 & Practice questions & $\begin{array}{l}\text { Questions with } 10 \text { multiple } \\
\text { choices which are completed } \\
\text { with score obtained by the } \\
\text { students after answering the } \\
\text { questions }\end{array}$ \\
\hline 8 & Bibliography & $\begin{array}{l}\text { References that are used as } \\
\text { guideline in compilingthe } \\
\text { material contained in the media }\end{array}$ \\
\hline 9 & Profile author & $\begin{array}{l}\text { Developer profile and } \\
\text { supervisor profile }\end{array}$ \\
\hline
\end{tabular}

Material validation is measured by 3 aspects. The results of material validation can be seen in Table 3.

Tabel 3. Material validation results

\begin{tabular}{ccccc}
\hline No & Rated aspect & Score & $\begin{array}{l}\text { Percentage } \\
(\mathbf{1 0 0 \% )}\end{array}$ & Category \\
\hline 1 & Learning design & 24 & $96,00 \%$ & Very Valid \\
2 & Contents & 37 & $92,50 \%$ & Very Valid \\
3 & Language and & 20 & $100,00 \%$ & Very Valid \\
& $\begin{array}{c}\text { Communication } \\
\quad \text { Sum }\end{array}$ & $\mathbf{8 1}$ & $\mathbf{9 6 , 1 6 \%}$ & Very Valid \\
\hline
\end{tabular}


Based on the data from Table 3, the percentage of learning outcomes given by websitebased science media material experts on invertebrate material is $96.16 \%$. This shows that in terms of material, the developed learning media is in the "Very Valid" category.

The results of this media validation were measured by 7 aspects. The results of media validation can be seen in Table 4.

Tabel 4. Media validation results

\begin{tabular}{|c|c|c|c|c|}
\hline No & Rated aspect & Score & $\begin{array}{c}\text { Percentage } \\
(\mathbf{1 0 0 \% )}\end{array}$ & Category \\
\hline 1 & Language & 19 & $95,00 \%$ & Very Valid \\
\hline 2 & $\begin{array}{ll}\text { Effects } & \text { of } \\
\text { Media } & \text { on } \\
\text { Learning } & \end{array}$ & 17 & $85,00 \%$ & Quite Valid \\
\hline 3 & Presentation & 37 & $92,50 \%$ & Very Valid \\
\hline 4 & $\begin{array}{c}\text { Full View } \\
\text { Sum }\end{array}$ & $\begin{array}{r}38 \\
111\end{array}$ & $\begin{array}{l}84,00 \% \\
89.12 \%\end{array}$ & $\begin{array}{l}\text { Quite Valid } \\
\text { Verv Valid }\end{array}$ \\
\hline
\end{tabular}

Based on Table 4, the results of the validation of the learning media that have been developed get the "Very Valid" category with a percentage value of $89.12 \%$, the websitebased learning media that has been developed is suitable for use by students.

Validation on science teachers was carried out to find out website-based science learning media on invertebrate animal material as a support for student learning. Based on Table 5, the results of the validation given by the science teacher for the learning media that have been developed get the "Very Valid" category with a total value of $89.83 \%$, so that the website-based learning media that has been developed is suitable for use by students.

Tabel 5. Science teacher validation results

\begin{tabular}{rcrrr}
\hline No & Rated aspect & Score & $\begin{array}{l}\text { Percentage } \\
(\mathbf{1 0 0 \% )})\end{array}$ & Category \\
\hline 1 & Learning design & 23 & $92,00 \%$ & Very Valid \\
2 & Contents & 37 & $92,50 \%$ & Very Valid \\
3 & Language and & 17 & $85,00 \%$ & Very Valid \\
Communication & & $\mathbf{7 7}$ & $\mathbf{8 9 , 8 3 \%}$ & Very Valid \\
\multicolumn{2}{c}{ Sum } &
\end{tabular}

This website-based science learning media has been validated by material experts, media experts and science teachers. The percentage of the results of the assessment given by the three experts can be seen in Table 6 .

Tabel 6. Expert validation results

\begin{tabular}{cccc}
\hline No & Rated aspect & $\begin{array}{l}\text { Percentage } \\
(\mathbf{1 0 0 \% )}\end{array}$ & Avarage \\
\hline 1 & Material & $96,16 \%$ & \\
& expert & & $91,70 \%$ \\
2 & Media expert & $89,12 \%$ & \\
3 & Science & $89,83 \%$ & \\
& teacher & & \\
\hline
\end{tabular}

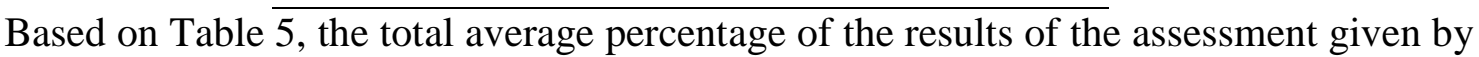
the experts to the website-based science learning media is $91.70 \%$. This shows that the website-based science learning media developed is in the "Very Valid" category.

In this case, the researcher presents to make it easier to see the assessment of the results of each aspect of the assessment by material experts, media experts, and science teachers. The results of the expert assessment are presented in graphical form in Figure 1. 


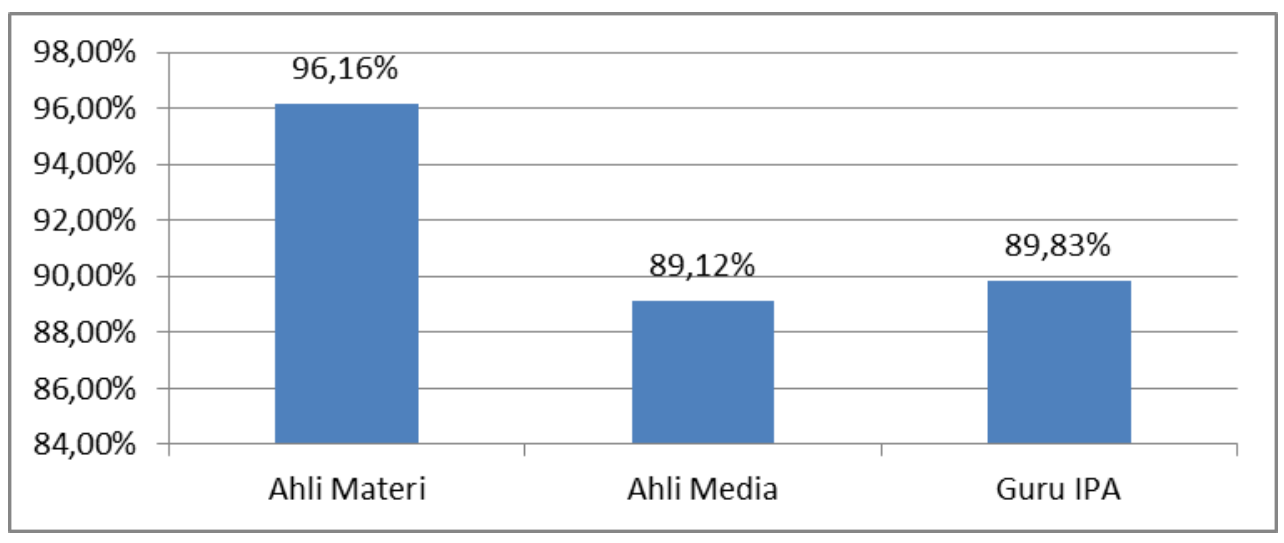

Figure 2. Expert Rating Chart

Student data responses were obtained by filling out a response questionnaire involving 6 students of class VII. The purpose of this is to determine the readability of the content by students as a whole against the media that has been developed before continuing on the largescale test stage. Score the results of student responses on a large scale. The results obtained from student responses on a small scale are $94.28 \%$, so it can be categorized as "Very Interesting" with the media being tested on a larger scale.

Student data responses on a large scale were carried out to determine student responses to website-based learning media involving 32 grade VII students. On a large scale obtained the category "Very Interesting" with a percentage value of $92 \%$.

The data responses in small scale and large scale can be seen in table 7.

Table 7. data respons from student

\begin{tabular}{ccccl}
\hline No & $\begin{array}{l}\text { The number of } \\
\text { students }\end{array}$ & Scale & $\begin{array}{c}\text { Percentage } \\
\mathbf{( 1 0 0 \% )}\end{array}$ & Category \\
\hline 1 & 6 & Small & $94,28 \%$ & Very interesting \\
2 & 32 & Large & $92 \%$ & Very interesting \\
\hline
\end{tabular}

Based on the table 7 that the result of data respons from students are very interesting. In small scale has function for show that the website based science learning media can read by students, then in large scale for show that students very interesting to learn about invertebrate animal topic in the website based science learning media. This is because students feel happy with the menus in website that makes it for them to understand the material.

\section{CONCLUSION}

This website-based science learning media for grade VII junior high school invertebrate animals was developed using the ADDIE development model developed by Robert Maribe Branch. This model has five stages, but in this study the researcher only used three stages, including Analysis, Design and Development. This website-based science learning media was developed with the aim of helping in the learning process. The material discussed in the media is invertebrate animal material which consists of eight phyla and their respective explanations. In addition, this media is equipped with color images and their role in everyday life.

The results of material validation obtained a percentage of $96.16 \%$ so that the material could be categorized as very valid. While the media validation obtained a percentage of $89.12 \%$, thus the media obtained a very valid category. Learning media is accessed online with the website address invertebratetadrisipa.com/. The website-based science learning media received a good response from students, this is based on the acquisition of student response scores on the small-scale test of $94.28 \%$ and the large-scale test of $92.00 \%$. So that it can be categorized as very interesting and the media will be even better if they pay attention to some suggestions from students, one of them; students want the material 
contained in the media not only for invertebrates but for other materials that are also developed with website-based media.

\section{REFERENCES}

A’yun, Dania Kurrotul dan Erman. 2019. Kemampuan Siswa Mengklasifikasi Kingdom Animalia Invertebrata: Studi Kasus Di SMP Negeri 1 Jabon.” Jurnal Pendidikan Sains.

Aditama, Putu Wirayudi, et. al. 2021. Pelatihan Penggunaan Microsoft Office Dan Email Untuk Administrasi Surat Menyurat Di Dinas Perhubungan Provinsi Bali. Jurnal Widya Laksmi 1. no 1.

Akbar, Sa'dun. Instrumen Perangkat Pembelajaran. Bandung: Remaja Rosdakarya.

Al-Qur'an, 16:125.

Aprianus, Erico dan Julianti Kasih. Perancangan Sistem Informasi Rental Sepeda Berbasis Web Pada Toko Linkz Cycle Pontianak. 2015. Jurnal Strategi 3, no. 1.

Arini, Ni Kadek Ayu Dwi, et. al. 2020. Korelasi Antara Rasa Ingin Tahu dan Motivasi Belajar dengan Hasil Belajar IPA Siswa Kelas V. Jurnal Mimbar Ilmu. 25, no. 1.

Aspahani, Elis Lisma et. al. 2020. Rancangan Media E-Poster Berbasis Website Pada Pembelajaran IPA di Sekolah Dasar. PEDADIDAKTIKA: Jurnal Ilmiah Pendidikan Guru Sekolah Dasar.

Azizah, Norma et. al. 2020. Pengembangan Media Scrapbook Pada Materi Bentuk Dan Fungsi Bagian Tubuh Pada Hewan Dan Tumbuhan. Jurnal Penelitian Pendidikan. 7, no. 2.

Bahagia dan Sriwinar. 2021. Implementasi J-Query Pada Aplikasi Monitoring Kehadiran Siswa Untuk Orang Tua Dengan Sms Gateway. Jurnal TIKA. 06, no. 01.

Campbell, Neil A. dan jane B. Reece. Biologi edisi kedelapan jilid 2, terj. Damaring tyas wulandari. Surabaya: PT. Gelora aksara pratama.

Dalimunthe, Nurmaini et. al. 2019. Evaluasi Website Pemko Pekanbaru Menggunakan Metode Heuristic Evaluation. Jurnal Ilmiah Rekayasa Dan Manajemen Sistem Informasi. 5, no. 2.

Dewi, Brigitta Elga Kusuma dan Woro Sumarni. Efektivitas Penggunaan Media E-Learning Berbasis Website Terhadap Hasil Belajar Kognitif Peserta Didik. 2020. Cie: Chemistry In Education.

Gunawan, Hendra Budi. 2015. Pengembangan Media Pembelajaran IPA Berbasis Website Pada Materi Pokok Perubahan Zat untuk Peserta Didik SMP/Mts. Skripsi, UIN Sunan Kalijaga, Yogyakarta.

Kimball, John W. 1983. Biologi Jilid 3 Edisi Kelima, terj. Siti Soetarmi Tjitrosomo dan Nawangsari Sugiri. Surabaya: PT. Gelora Aksara Pratama.

Kustandi, Cecep dan Bambang Sutjipto. Media Pembelajaran Manual dan Digital. Jakarta: Ghalia Indonesia.

Lestari, Putu Astri dan Ni Putu Emilika Budi Lestari. 2019. Pelatihan Aplikasi Perkantoran Menggunakan Microsoft Office Di Panti Asuhan Rumah Impian Kota Denpasar. Jurnal Lentera Widya. 1, no. 1 ..

Mariana, I Made Alit dan Wandy Praginda. 2019. Hakikat IPA dan Pendidikan IPA. Pusat Pengembangan dan Pemberdayaan Pendidik dan Tenaga Kependidikan Ilmu Pengetahuan Alam.

Maryanto, Budi. 2018. Memanfaatkan Cascading Style Sheet untuk Memperindah Tampilan Web. Jurnal Media Informatika. 8 no. 2.

Mustaqim, Ilmawan. 2016. Pemanfaatan Augmented Reality Sebagai Media Pembelajaran. Jurnal Pendidikan Teknologi dan Kejuruan. 13, no. 2.

Observasi di SMPN 1 Tegaldlimo, 10 September 2020. 
Pito, Abdul Haris. 2018. Media Pembelajaran Dalam Perspektif Alquran. Jurnal Diklat Teknis VI.

Pratiwi, Olyfia. 2019. Pengembangan Media Pembelajaran Biologi Berbasis Web Pada Materi Evolusi Kelas XII Di SMA Negeri 1 Meulaboh. Skripsi, Universitas Islam Negeri Ar-Raniry. Banda Aceh.

Rais, Muh. dan Mochammad Apriyadi Hadi Sirad. 2019. Inventory Information System Of Goods Using Codeigniter Framework. Patria Artha Technological Journal. 3, 1.

Rivanthio, Tubagus Riko. 2020. Perancangan Pengajuan Sidang Laporan Praktek Kerja Lapangan Mahasiswa Berbasis Website Pada Sekolah Tinggi Analis Bakti Asih Bandung. Jurnal Teknologi Informasi Dan Komunikasi. 7, no. 1.

Sadikin, Ali et. al. 2015. Pengembangan Multimedia Interaktif Biologi Berbasis Website Dalam Menghadapi Revolusi Industri 4.0. Edubiotik: Jurnal Pendidikan, Biologi dan Terapan. 5, no. 1.

Sahlan. 2015. Evaluasi Pembelajaran: Panduan Praktis Bagi Pendidik dan Calon Pendidik. Jember: STAIN Press.

Sanaky, Hujair Ah. 2015. Media Pembelajaran Interaktif-Inovatif. Yogyakarta: Kaukaba Dipantara.

Sasinggala, Metilistina et. al. 2020. Identifikasi Jenis Hewan Dominan Di Ekosistem Hutan Sekitar Kampus Unima Sebagai Referensi Bahan Pembelajaran Eksploratif. JSME (Jurnal Sains, Matematika, Dan Edukasi). 8, no. 2.

Sekretariat Nerara RI, Undang-undang No. 20 tahun 2003 tentang Sistem Pendidikan Nasional.

Sholekah, Anis Wahdati. 2020. Peningkatan Motivasi dan Hasil Belajar IPA Materi Pencemaran Lingkungan Melalui Model PjBL Siswa Kelas VII SMPN 9 Salatiga.” Jurnal Pendidikan MIPA. 10, no. 1.

Suendarti, Mamik dan Hasbullah. 2020. Pemahaman Konsep Ilmu Pengetahuan. Sinasis. 1, no. 1 .

Sugiyono. 2019. Metode Penelitian Dan Pengembangan (Research And Development). Bandung: Alfabeta.

Trisiana, Anita dan Wartoyo. 2007. Desain Pengembangan Model Pembelajaran Pendidikan Kewarganegaraan Melalui ADDIE Model Untuk Meningkatkan Karakter Mahasiswa Di Universitas Slamet Riyadi Surakarta. Jurnal Pkn Progresif. 11, no. 1.

Uno, Hamzah B. dan Abd. Rahman K. Ma'ruf. 2016. Pengembangan Media Pembelajaran IPS Berbasis Website untuk Siswa Kelas VII Madrasah Tsanawiyah Negeri. Jurnal Teknologi Pendidikan. 18, no. 3.

Utami, Riska Setyo et. al. 2020. Pengembangan Media Pembelajaran Berbasis Website Tema 6 Subtema 1 Kelas IV. Seminar Nasional PGSD Unikama. 4.

Zakiyyah, Fitri. 2018. Pengembangan Media Pembelajaran Biologi Berbasis Web Terintegrasi Nilai Keislaman Pada Materi Struktur Dan Fungsi Jaringan Hewan Di Kelas XI Ma Futuhiyyah 2 Mranggen Demak. (Skripsi, Universitas Islam Negeri Walisongo Semarang, 2018). 